\title{
Coastal flooding by tropical cyclones and sea-level rise
}

\author{
Jonathan D. Woodruff ${ }^{1}$, Jennifer L. Irish ${ }^{2} \&$ Suzana J. Camargo ${ }^{3}$
}

The future impacts of climate change on landfalling tropical cyclones are unclear. Regardless of this uncertainty, flooding by tropical cyclones will increase as a result of accelerated sea-level rise. Under similar rates of rapid sea-level rise during the early Holocene epoch most low-lying sedimentary coastlines were generally much less resilient to storm impacts. Society must learn to live with a rapidly evolving shoreline that is increasingly prone to flooding from tropical cyclones. These impacts can be mitigated partly with adaptive strategies, which include careful stewardship of sediments and reductions in human-induced land subsidence.

$\mathrm{F}$ looding in the context of future storm variability, sea-level rise and shoreline change is one of the most important issues facing coastal populations today. In the regions they affect, tropical cyclones are often the most damaging storms and, therefore, of primary importance when assessing flood risk. It is clear that coastal populations are becoming more prone to extreme flooding from tropical cyclones ${ }^{1}$. There is also growing evidence for a future shift in the average global intensity of tropical cyclones towards stronger storms ${ }^{2}$. Although both of these two points are probably true, most researchers would agree that linking the two in terms of cause and effect is in many ways incorrect.

First, significant uncertainty exists as to how tropical cyclone activity will vary regionally, particularly with respect to landfalling storms. Second, the level of regional tropical cyclone activity is just one of the factors that drives the magnitude and frequency of tropical cyclone flooding. For example, the Western North Pacific has been the most prolific tropical cyclone basin over the instrumental record, both in terms of the overall number of tropical cyclones (30\% of global activity) and peak tropical cyclone wind intensities (Fig. 1). However, in recent decades this basin accounted for neither the majority of economic nor human losses from tropical cyclones. These records have been held by two of the least active tropical cyclone basins, the North Atlantic (10\% of global tropical cyclone activity) and North Indian Ocean (5\% of global tropical cyclone activity), respectively. Since 1970, around 65\% of all lives lost as a result of tropical cyclones occurred within the North Indian Ocean equivalent to more than half a million deaths ${ }^{3}$. Over this same period, more than $60 \%$ of all economic losses from tropical cyclones took place in the North Atlantic - amounting to around US $\$ 400$ billion $^{3}$.

Although tropical cyclone activity is relatively low in the North Indian Ocean and the North Atlantic, the frequency of coastal flooding is not. Extreme flooding is prevalent mainly on low-gradient shores, including barrier and deltaic systems; these areas have often also attracted the development of dense population centres. Low-lying coasts are typically composed of soft sediments and are particularly dynamic, with geometries that greatly enhance storm impacts. For these evolving shores, storms provide the dominant mechanism of extreme flooding and erosion - although in this Review we discuss how it is often sealevel rise (SLR) that is the underlying cause of both increasing rates of long-term shoreline retreat and flood frequency. Human factors are of equal importance in terms of influencing coastal impacts by tropical cyclones $^{1,4,5}$, but this topic is beyond the scope of this Review. However, at the root of these human factors is the flood-prone landscape on which coastal populations have developed. In these settings, joint consideration of tropical cyclone climatology, relative SLR and shoreline change is crucial for accurate assessments of future flood risks. We focus this Review on these three physical factors, highlighting that rising sea levels will become a dominant driver of increased tropical cyclone flooding irrespective of changes in tropical cyclone activity. We point to population centres most at risk of tropical cyclone impacts - those that are mainly located along dynamic and subsiding sedimentary coasts that will serve to further enhance the impact of future tropical cyclone floods. Finally, we discuss managing risk in the context of an almost certain increase in tropical cyclone flood frequency, and the importance of using a holistic approach to manage coastal systems.

\section{Tropical cyclone climatology}

On average, about 90 tropical cyclones occur worldwide per year, with the annual distribution of these events varying among the various tropical cyclone basins ${ }^{6}$. Only about one-fifth of tropical cyclones make landfall with the intensity of a hurricane (defined by wind speeds $\geq 33 \mathrm{~ms}^{-1}$ ), but coastal impacts by tropical cyclones are due largely to this important subset of storms ${ }^{7}$. Accumulated cyclone energy (ACE) is a common metric for comparing the overall tropical cyclone activity of different tropical cyclone regions; it is calculated by taking the sum of each tropical cyclone's maximum wind speed squared for all storms passing through a selected area. Storm surge is also related to wind speed squared (discussed later), thus ACE is a useful measure of both tropical cyclone activity and tropical cyclone surge potential, all else being equal (for example, ignoring the configuration of a coastline and bathymetry). Spatial variability in ACE highlights anomalously high levels of tropical cyclone activity in the North Pacific, relative to the substantially lower levels of activity within the other tropical cyclone regions (Fig. 1a).

\section{Environmental influences}

A warm upper ocean, represented by sea surface temperature (SST), is one of the requirements for tropical cyclone formation and intensification, as is evident by the modulation of tropical cyclone activity in response to the seasons ${ }^{8}$. All else being equal, SST directly relates to the theoretical maximum wind speed that tropical cyclones can reach under specific local environmental conditions ${ }^{9}$. This theoretical maximum wind speed, or potential intensity (PI), is also inversely related to 
a

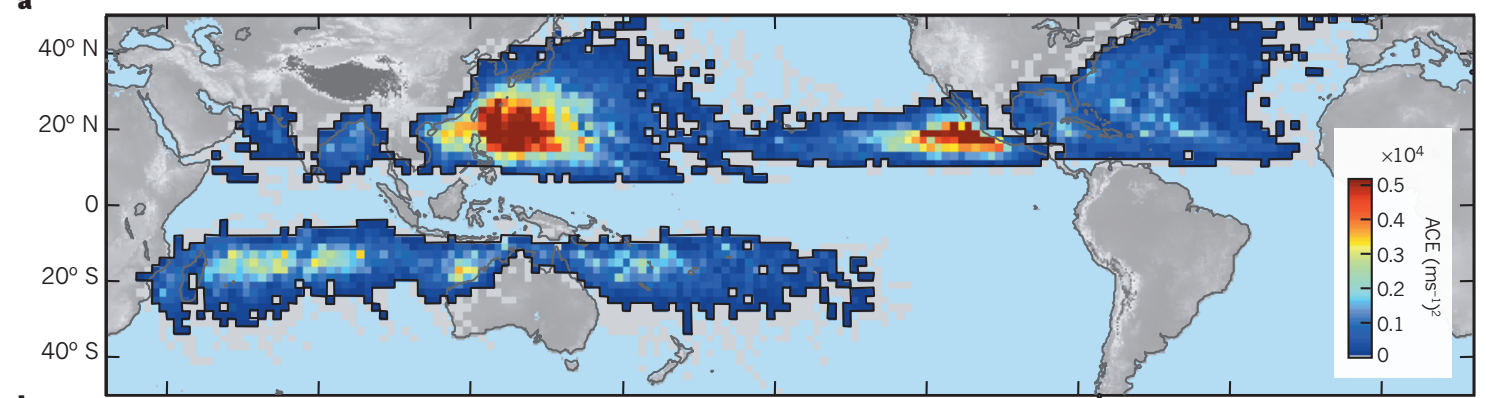

b

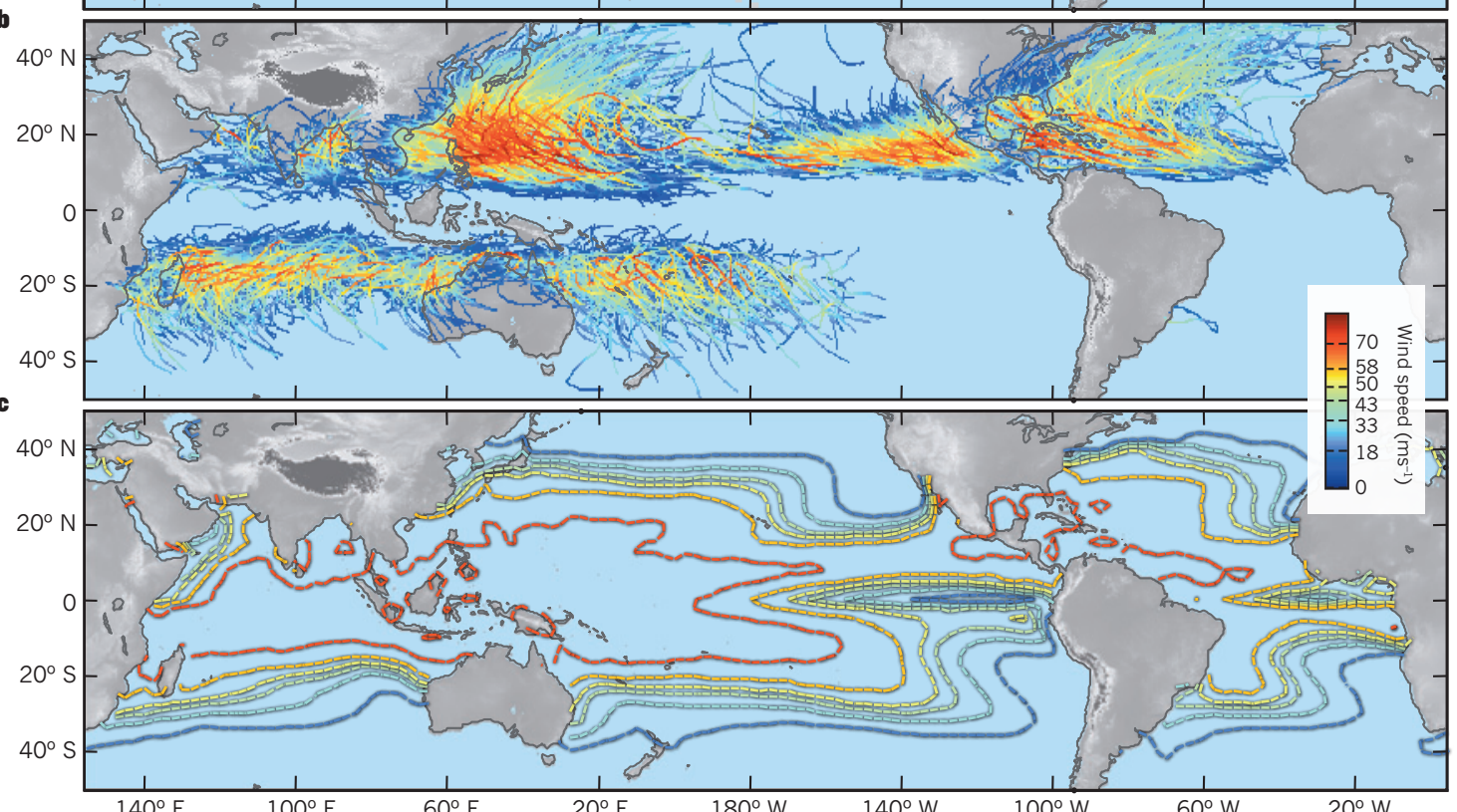

Figure 1 | Global tropical cyclone activity for the period 1981-2010. a, Accumulated cyclone energy (ACE). In the Northern Hemisphere, ACE is highest in the western and eastern North Pacific, with lower values in the North Atlantic and Indian Oceans. In the Southern Hemisphere, ACE is highest in the South Indian Ocean. b, Historical tropical cyclone tracks. Tracks of intense tropical cyclones concentrate in the western and eastern North Pacific regions, with fewer occurring in the North Atlantic and Southern Hemisphere. Colour scale refers to intensities of tropical cyclone tracks. c, Potential intensity for the western North Atlantic and eastern

North Pacific ${ }^{87}$, western North and South Pacific and Indian Ocean ${ }^{88}$, and South Atlantic ${ }^{89}$. Colour scale is the same as in $\mathbf{b}$ and refers to potential intensity wind speed contours. In the North Atlantic and eastern North Pacific, tropical cyclones with maximum 1 minute sustained wind speeds in excess of $33 \mathrm{~ms}^{-1}$ are classified as hurricanes, whereas in the western North Pacific storms meeting this same criterion are called typhoons, and in the Southern Hemisphere they are called severe tropical cyclones. Hurricanes with wind speeds in excess of $50 \mathrm{~ms}^{-1}$ are defined as major hurricanes (Categories 3-5).

the outflow temperature where rising air exits a tropical cyclone. The difference between the observed distribution and intensity of tropical cyclone activity (Fig. 1a, b) and PI (Fig. 1c) is due to other environmental factors that are also important in determining tropical cyclone frequency ${ }^{10,11}$. For example, in the South Atlantic tropical cyclones are scarce (Fig. 1b), despite having a relatively high PI (Fig. 1c). Wind speed in the South Atlantic varies greatly with height in the troposphere (high values of vertical wind shear), which is one important reason for tropical cyclone scarcity in the basin. High vertical wind shear is also a central mechanism for inhibiting tropical cyclone frequency and intensity in the other tropical cyclone regions ${ }^{10,12,13}$. The amount of humidity in the atmosphere and the presence of pre-existing disturbances, in the form of atmospheric waves and storms that are precursors for tropical cyclone formation also have an important influence on tropical cyclone frequency. All of these factors should be taken into account in future tropical cyclone projections.

\section{Future projections}

At the end of the twenty-first century there will probably be fewer, but stronger, storms globally ${ }^{2}$. However, the magnitude range for these predicted changes is still wide, because the different models used to make these projections exhibit different sensitivities to climate change. For

example, projections for changes in the number of tropical cyclones range from -6 to $-34 \%$ globally, with increases in mean tropical cyclone global wind speed ranging between 2 to $11 \%$ by the end of the twentyfirst century ${ }^{2}$. Significantly greater uncertainty exists with respect to how tropical cyclone activity will vary regionally, with projected changes up to $\pm 50 \%$ in the number of tropical cyclones in individual tropical cyclone basins by the end of the twenty-first century ${ }^{2}$. Similarly, not all ocean basins may experience an increase in tropical cyclone intensity. A statistical downscaling of the tropical cyclone projections of the Coupled Model Intercomparison Project Phase 5 (CMIP5) shows a probable increase in tropical cyclone frequency in the first half of the twentyfirst century in the North Atlantic, but the trends in North Atlantic tropical cyclone frequency by the end of the twenty-first century are still uncertain ${ }^{14}$. By contrast, North Atlantic tropical cyclone intensity is projected to increase in all climate scenarios by the end of the twentyfirst century ${ }^{15}$.

Modes of climate variability such as the El Niño-Southern Oscillation (ENSO) and the Madden-Julian Oscillation (MJO) can have a strong regional influence on tropical cyclone frequency and intensity ${ }^{10,12,16,17}$, and current uncertainties in ENSO and MJO have contributed to the difficulties in obtaining robust global-specific and basin-specific projections ${ }^{18,19}$. A number of other natural climate modes on various 


\section{BOX 1}

\section{Tropical cyclone probabilities}

Evaluating changes related to tropical cyclone impacts requires a general understanding of the statistical metrics conventionally used for their assessment. The likelihood of winds or flood levels exceeding a threshold is often presented either as the probability of occurrence in a particular year, or with a return period equal to the inverse of this annual probability. For example, a $1 \%$ probability of winds or floodwaters exceeding a certain level in any year is equivalent to the event having a 100-year return period. Another useful metric of hazard exposure is the chance that a certain extreme event will be exceeded over a specified interval of time:

$R=1-(1-Q)^{T}$

where $R$ is the chance of an event with an annual exceedance probability of $Q$ occurring over the time period $T^{99}$. This relationship reveals that there is a $63 \%$ chance of a 100 -year event $(Q=1.0 \%)$ occurring in the next 100 years, and a $10 \%$ chance of a 1,000 -year event $(Q=0.1 \%)$ occurring in the next 100 years. This $10 \%$ is still fairly high and serves to highlight why coastal planners often consider events with return periods well beyond the time frame of interest, particularly with respect to sensitive infrastructure. However, the probability of these low-frequency events are the most difficult to constrain, particularly in the context of changes to tropical cyclone climatology.

timescales also influence tropical cyclones in different regions ${ }^{20}$, and are a source of additional uncertainty. Furthermore, future changes in hybrid storm frequency, including tropical cyclones that undergo extratropical transition, such as Hurricane Sandy in 2012, are largely unknown ${ }^{21}$.

Currently, modes of climate variability, including ENSO and MJO, explain roughly $30-45 \%$ of tropical cyclone activity variance within the instrumental historical record ${ }^{6}$. The percentage is much less, however, when considering only storms that make landfall. Furthermore, although these modes of climate variability modulate landfall probabilities in large regions, exact landfall locations are determined by storm tracks, and there is significant variability in tracks both season-to-season and within a single season ${ }^{22}$. Landfall probabilities are often described as a stochastic process given the high uncertainty associated with local tropical cyclone activity, particularly on shorter timescales (Box 1).

\section{Sea-level rise and tropical cyclone flooding}

Global sea level is expected to rise in the upcoming centuries, with a mean global increase that could approach or exceed $1 \mathrm{~m}$ by 2100 (ref. 23). SLR is also expected to continue to accelerate through the twenty-first century. Relative SLR at individual sites will vary from this global average $^{24}$; however, in general, densely populated regions affected by coastal flooding from tropical cyclones have experienced a rate of SLR near or greater than the global average over the instrumental record (Fig. 2).

Before the satellite era, instrumental records of SLR are mostly derived from tide gauges, which record long-term sea-level trends, as well as the sudden rise in water level associated with storm events. Analyses of these time series indicate an increase in extreme high water levels worldwide since 1970, with this increase due almost exclusively to SLR rather than changes in storm climatology ${ }^{25}$. Longer tide-gauge records along the East Coast of the United States reveal similar results ${ }^{26}$. However, tide gauge data alone is generally too short to obtain meaningful extreme value statistics ${ }^{27}$, with derived probabilities that do not account for future, potentially higher, magnitude changes in both sealevel and tropical cyclone activity.

\section{Controls on flooding}

Storm surge induced by tropical cyclones depends greatly on coastal geometries, including topography, local shoreline configurations and depth, and individual tropical cyclone characteristics - predominantly the wind speed, storm size and landfall location. The storm's forward motion, angle of approach, and atmospheric pressure drop also influence surge generation. Tidal range and storm timing with the tide; the increase in water level, owing to the presence and local behaviour of shoaling waves; and river discharge and rainfall-driven runoff also contribute to flooding. However, in coastal regions that experience the most extreme tropical cyclone flooding, the greatest elevated water levels are largely due to wind-driven storm surge. Using a linearized momentum conservation argument, for which bottom friction and other external forces are neglected, it can be shown that wind surge is proportional to:

$$
U^{2} \frac{W}{h}
$$

where $U$ is wind speed, $W$ is the distance over which the wind blows in the same direction, and $h$ is the mean depth over the region where the wind blows ${ }^{28}$. As equation (1) indicates, wind-driven surge is mainly generated in relatively shallow depths, and where shallow waters extend far offshore. Thus, areas with a relatively broad and shallow continental shelf, such as the western North Atlantic, generally have larger winddriven surge than areas where offshore slopes are steep, such as the mountainous islands of the western North Pacific and the Caribbean (Fig. 3). However, deltaic low-lying coasts along otherwise steep, less habitable terrain are also particularly susceptible to enhanced tropical cyclone flooding - for example, many of the large population centres in the Bay of Bengal, and sites of growing vulnerability in the western North Pacific ${ }^{29,30}$ (Fig. 3b).

Equation (1) also shows that storm surge is expected to increase with the square of tropical cyclone wind speed. As an example, if tropical cyclone wind intensity for a given tropical cyclone increases by $4 \%$ for each degree Celsius of SST warming ${ }^{31,32}$, from equation (1) we can expect wind surge to increase by $8 \%$ for each degree Celsius of SST warming. Damage from storm winds is related to the wind speed cubed, thus compounding impacts related to warming SST ${ }^{33}$. However, the approximation for tropical cyclone intensification as a function of warming SST neglects key meteorological influences, which have been discussed previously, including humidity, winds and atmospheric temperature.

\section{Future projections}

Coastal flooding probability associated with landfalling tropical cyclones depends both on the probability of tropical cyclone occurrence and the behaviour of relative sea level. Accurate predictions of future flood risk, therefore, must consider the two jointly. The specific role of SLR and the potentially higher occurrence of intense storms in future tropical cyclone flooding have been the focus of a number of recent studies ${ }^{34-39}$. Many studies assume that tropical cyclone surge and SLR are independent, thus the two may be linearly summed: flood elevation equals surge plus SLR. This approach is a relatively simplistic means of obtaining a global forecast of changes in extreme flood probabilities and associated risk to coastal populations ${ }^{34,35}$. Although SLR 
rates, storm intensification, and time periods differ among studies, the general consensus is for an increase in future extreme flood elevations.

More sophisticated techniques that include a hydrodynamic modelling component directly consider non-linearities between SLR and storm surge $\mathrm{e}^{36,37,39,40}$. Simulations in surge-prone Bangladesh were among the first numerical studies to consider both SLR and a potential increase in the tropical cyclone occurrence ${ }^{36}$. Results show that projected SLR by the 2050s, along with the increased occurrence of intense storms, may inundate up to $15 \%$ of the country and could result in a $12 \%$ rise in water levels by extreme events. In a more recent study along the coastline of Cairns, Australia, the 100-year return period of a flood event was decreased to a 40-year event using statistically generated storms for the 2050 s, along with $0.2 \mathrm{~m}$ of SLR and a $10 \%$ increase in storm wind speeds $^{37}$. To assess the combined impact of SLR and changes in tropical cyclone activity for the Atlantic basin a modified joint probability method has been proposed ${ }^{38}$. For the fourth Intergovernmental Panel on Climate Change (IPCC) "middle-of-the-road" scenario (A1B) on an idealized coast, this study projects the present-day 100 -year return period flood elevation becoming the 60 -year event by the 2050s. All of the above mentioned results are for relatively moderate rates of SLR by the 2050s and do not account for the more rapid rates of SLR projected for the latter half of the twenty-first century (Fig. 2).

Enhanced rates of relative SLR in regions of rapid land subsidence will further amplify tropical cyclone flooding. This enhanced subsidence is common along populated deltaic and coastal plain systems owing to groundwater, oil and gas extraction, and reductions in fluvial sediment supply. Megacities where past rates of human-induced subsidence exceeded an average of $1 \mathrm{~cm} \mathrm{yr}^{-1}$ include Osaka, Japan $(2.8 \mathrm{~m}$ of subsidence between 1935 and 1995); Manila, Philippines (>1 m of subsidence between 1991 and 2003); Tainjin, China (3.1 m of subsidence between 1959 and 2003); and Tokyo, Japan (5 m of subsidence between 1930 and $1995)^{41,42}$. Shanghai, China, is one of the largest megacities that could potentially be affected by elevated rates of relative SLR ( $2.8 \mathrm{~m}$ of subsidence between 1921 and 1995) ${ }^{42}$. Here a $4.3 \mathrm{~m}$ projected rise in sea level due to additional land subsidence along the Yangtze River delta by 2100 would result in half of Shanghai being flooded by extreme storm-water levels ${ }^{43}$. Similar increases in tropical cyclone impacts are projected at other locations where SLR rates are expected to significantly exceed the global average - for example the Red River Delta, Vietnam ${ }^{44}$, and the Mississippi Delta ${ }^{45}$. All of these conclusions assume that no countermeasures are taken to alleviate artificial causes of land subsidence.
One of the most comprehensive projection studies of the combined influence of recent SLR projections and future tropical cyclone climate on storm surge assesses changes in flood probabilities in the New York City region at the end of the twenty-first century ${ }^{39}$. In this study, a nested modelling technique was used, combining output from global climate model simulations with a physical tropical cyclone model to generate synthetic tropical cyclone tracks for driving hydrodynamic storm surge simulations. Results differ greatly depending on the climate model used, with changes in the return frequency of tropical storms in the New York region ranging from $-15 \%$ to $290 \%$ by the end of the twenty-first century. However, all simulations show increased flooding when a $1 \mathrm{~m}$ rise in sea level is included, with the present-day 100-year return period flood event reduced to the 3-20 year event (Box 2 discusses SLR and flooding by Hurricane Sandy in 2012).

These studies highlight current uncertainties associated with future changes in flood frequency that are linked with variability of landfalling tropical cyclones. More importantly, however, they all point to the clear increase in flood frequency associated with an accelerating SLR, regardless of tropical cyclone climatology projections.

\section{Shoreline dynamics}

Recent results highlight the importance of relative SLR in increasing coastal flood frequency ${ }^{34,35-39}$. However, the compounding effects of future shoreline change are not accounted for in most of these assessments. Potential changes in tidal regime may also be important ${ }^{46}$. Coastlines vary greatly in their morphology; however, broad low-lying regions at the greatest risk of tropical cyclone flooding generally share the commonality of being fairly dynamic (Fig. 3). These low-lying shores are often built by mobile sediments (for example, barrier beaches and deltaic coastlines) and/or by biogenic systems (for example, reefs, mangrove wetlands and salt marshes) that are particularly susceptible to climatic and anthropogenic stressors ${ }^{47-49}$. The frequency and intensity of tropical cyclone flooding has been, and will continue to be, tightly coupled to the morphological development of these coastal systems.

\section{Geomorphic function of tropical cyclones}

Tropical cyclones are natural phenomena that have greatly contributed to the morphology of modern shorelines. In many cases, storms serve as a construction mechanism. For instance, sands along the back of barrier beaches are largely storm derived. Deposits from sediments overwashing barrier islands might provide a key mechanism for determining

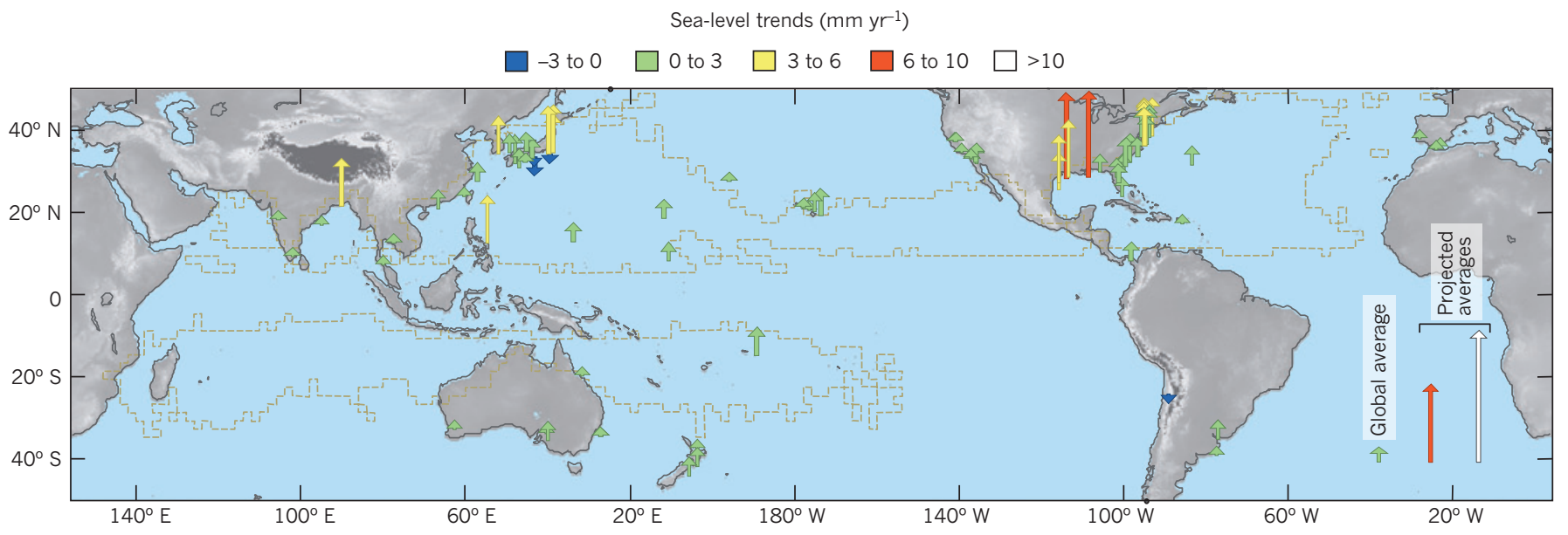

Figure 2 | Global sea-level trends. Local sea-level trends based on individual tidal gauge records more than 50 years old $\mathrm{ol}^{24,90}$. Green arrows indicate regions where rates of SLR have been near the long-term global average, whereas red and yellow indicate areas where SLR exceeds the global mean. For comparison, arrows on the bottom right show (from left to right) the global instrumental averages from 1900 to present, the projected average rate from present to 2100 , and the projected rate at 2100 (ref. 23; see Fig. $4 \mathrm{~b}$ for SLR time series derived from ref. 23). Dashed lines outline regions of tropical cyclone activity defined by ACE in Fig. 1a. Spatial coverage is limited by the availability of long-term tide gauge records. However, most of the key population centres affected by tropical cyclones are focused in locations of rising sea level. For instance, by 2020 , of the world's top 30 megacities 13 are projected to be along coasts affected by tropical cyclones ${ }^{91}$ (see Fig. 3 for locations). With the exception of Chennai, India, all of these population centres have experienced a rise in relative sea level in recent decades, with rates at 10 of these 13 locations greater than the global mean ${ }^{41,90,92,93}$. Figure adapted with permission from ref. 94 . 

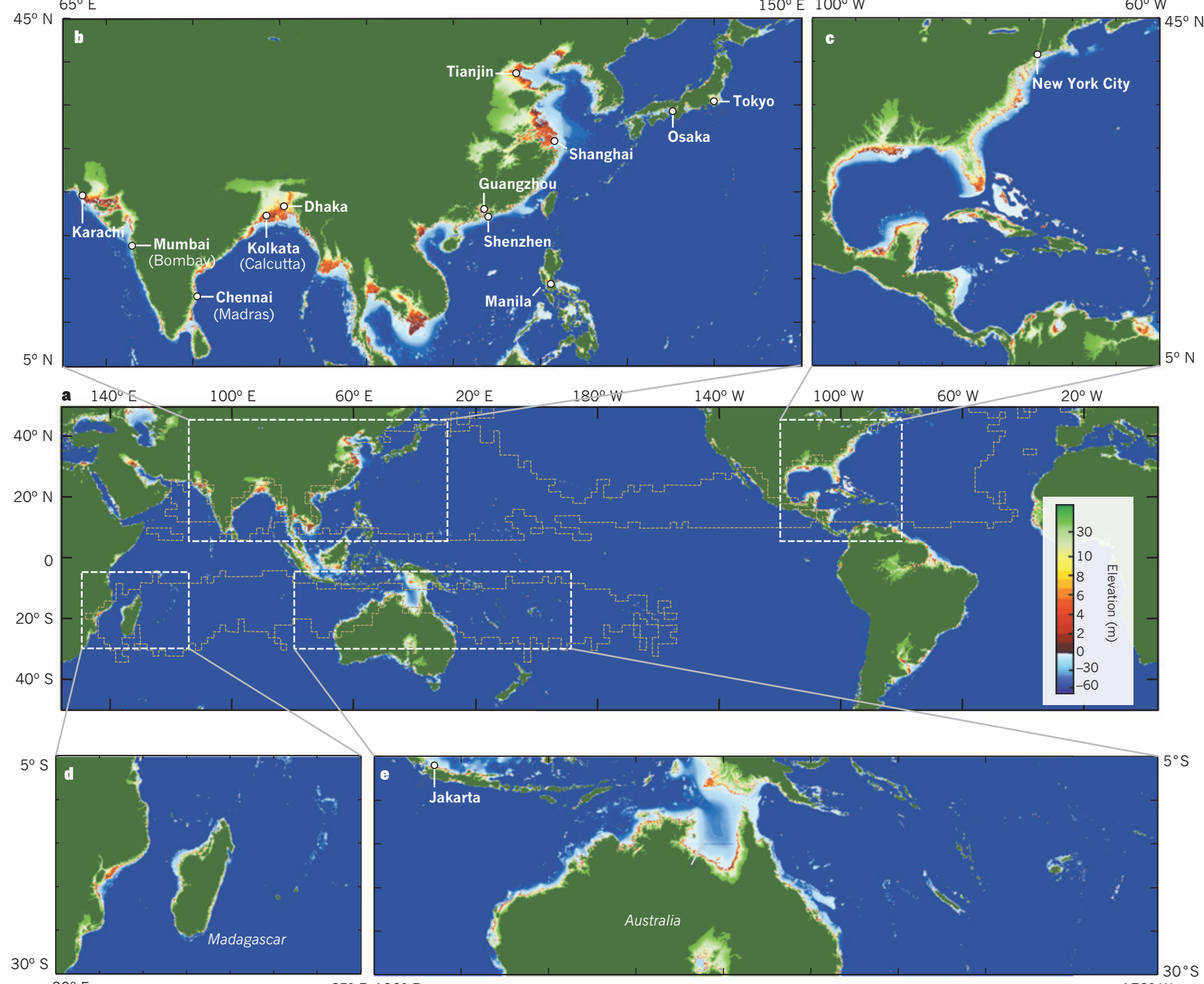

Figure 3 | Coastlines with broad low-lying elevations and shallow abutting bathymetry. a, Regions where storm surge is enhanced by shallow depths offshore are shown in pale blue, and low-lying regions generally at a greater risk of coastal flooding are shown in red. Regions of tropical cyclone activity defined by ACE (Fig. 1a) are outlined by grey dashed lines in a. Broad regions of low-lying topography and shallow near-shore bathymetry are a fairly good proxy for dynamic and evolving low-gradient shorelines. b, The expansive low-lying regions in the Western North Pacific and North Indian Ocean are mainly along deltaic systems that are composed of unconsolidated subsiding sediments. c, Similarly, most of the low-lying coasts affected by tropical cyclones in the Gulf of Mexico and the Western North Atlantic are composed of soft sediments often fronted by dynamic barrier beach systems. Finally, small-island nations affected by tropical cyclones, often identified in $\mathbf{b}-\mathbf{e}$ as isolated light blue regions, are typically fronted by living reef and mangrove systems, which are particularly sensitive to changing environmental conditions. Topographic and bathymetric data are from ref. 95. Coastal cities indicated with circles are ranked among the top 30 of the world's largest urban centres by 2025 (ref. 91). vertical accretion rates within back-barrier marshes ${ }^{50-52}$. Furthermore, waves from distant tropical cyclones frequently mobilize offshore sediments that are normally unavailable for littoral transport, allowing this material to be redistributed along the shore face and shallow shelf ${ }^{53}$. Storms are also largely responsible for sediment redistribution across barrier reef systems ${ }^{54}$, as well as the building of successive beach ridges along seaward advancing or prograding coastlines (commonly referred to as beach ridge plains) ${ }^{55}$

Naturally, tropical cyclones also erode shorelines, and the building of back-barrier environments often occurs at the expense of an eroding foreshore ${ }^{49,56}$. Ultimately, this net transport of sediment from the foreshore to the backshore results in the landward retreat of the entire barrier beach system through a barrier rollover mechanism ${ }^{49}$. Mechanisms of shoreline retreat can be complex, with rates governed not only by SLR, but also by sediment supply and the coastline's pre-existing configuration and lithology (geological or glacial inheritance). The opening of new inlets by storms can also be particularly destructive to barriers because this is often where the greatest loss of beach sediment is observed ${ }^{57-59}$. Newly formed tidal inlet deltas act as a significant sink for beach sediments. The opening of new inlets can also measurably change tidal exchange and allow ocean surges to more effectively propagate inland. Thus, the surge hazard will be significantly greater if a tropical cyclone occurs while a new inlet remains open. Similarly, inland areas become more vulnerable to tropical cyclone surges through barrier island degradation and inlet formation. Although wide and high barrier islands serve as a natural surge impediment, degraded narrow, low barrier islands readily allow overwash and breaching during tropical cyclones, leading to increased surge levels behind these coastal barriers ${ }^{60}$. 
Potentially, many of these coastal systems have tipping points, at which coupled changes in SLR, vegetation coverage and sediment supply result in rapid conversion from one equilibrium state to another, for example gradual barrier island migration compared with complete break up of the barrier island system ${ }^{49}$, or salt marshes compared with open-water tidal flats ${ }^{61,62}$. Furthermore, the landward retreat of inhabited barrier beaches is inhibited by artificial structures, resulting in shoreline degradation and a loss of the natural buffer that protects infrastructure and homes from large wave forces during tropical cyclone events.

Although initial damage to coastal landforms by tropical cyclones often seems catastrophic, given enough time, these coastal systems generally have the means to recover. The entire barrier beach profile can rebuild if there is sufficient sediment supply ${ }^{57,63}$, storm-produced inlets can close, and vegetative cover and reef systems can regrow ${ }^{64}$. Shoreline resilience to severe tropical cyclone disturbance requires that enough time lapses between extreme events to allow for recovery; barrier ${ }^{57,65}$ and reef systems ${ }^{66}$ are particularly vulnerable to subsequent flood events during this recovery period.

Tropical cyclone climatology partly drives the length of recovery time that coastal systems have between storm disruptions. However, extreme-value flood statistics consistently point towards SLR as a competing, if not more important, factor in driving the frequency of extreme coastal flooding by tropical cyclones. Thus, although storms provide the dominant mechanism for erosion, it is often an increase in SLR and/or a drop in sediment supply that is the true underlying cause of long-term rates of shoreline retreat ${ }^{63}$.

\section{Insight from Holocene shoreline development.}

Global SLR rates during the early Holocene (roughly 11,500 to 7,000 years before present), are of the same order as many current projections of global SLR by the end of the twenty-first century, about $1 \mathrm{~cm} \mathrm{yr}^{-1}$ (Fig. 4). The form and behaviour of shorelines during this earlier period of rapid SLR therefore serves as an important analogue of future shoreline change (although differences exist, including the location of the coast and sediment availability). Often, SLR during this time period was too fast for landforms such as barrier beaches to remain stable, resulting in submergence or rapid landward retreat of these systems ${ }^{67}$. Remnants of relic back-barrier salt marsh and estuarine material are observed kilometres offshore and are evidence of substantial shoreline retreat during the early to mid-Holocene ${ }^{68,69}$. This period of wide-spread shoreline instability is commonly referred to as the Holocene transgression, a period of rapid landward retreat of many low-lying sedimentary coastlines in response to high rates of SLR.

In general, the configuration and current function of most modern low-gradient shorelines only established themselves after a significant decline in global SLR rates, beginning around 9,000 to 6,000 years ago (Fig. 4). Rates of sea-level change for the next 6,000 years or so vary regionally ${ }^{70}$, from areas of little change to areas of both net SLR and net sea-level fall. However, with the exception of regions of significant tectonic activity or rapid isostatic adjustment, most coastlines affected by tropical cyclones have experienced moderate rates of sea-level change over the past few millennia relative to the rapid SLR rates of the early Holocene. Examples of current coastal settings, for which the existing forms and behaviours commonly established themselves under these fairly modest rates of sea-level change, include most of the world's deltaic systems $s^{71}$, barrier beaches ${ }^{67,72,73}$, contemporary beach ridge and chenier plains ${ }^{74,75}$, wetland marshes $\mathrm{s}^{76,77}$ and mangrove wetlands ${ }^{78,79}$.

Although rates of sea-level change remained relatively low over the later Holocene, tropical cyclone activity did not (Fig. 4c). Statistically significant intervals of both quiescence and increased tropical cyclone activity are evident in the timing of coarse-grained, tropical-cycloneinduced event deposits from back-barrier salt marshes and coastal ponds ${ }^{80,81}$. Overwash deposits can be delineated within these backbarrier environments because they are later covered by finer-grained organic substrate once sheltered conditions resume. These palaeo-storm records, therefore, not only provide evidence of changes in storm activity over the past few millennia, but they also point to the resilience of barrier beach systems to storms during times of modest sea-level change. By contrast, there is a lack of early Holocene storm deposits preserved behind the modern coast, which points to the seaward location of past shorelines and the frequent reworking of back-barrier sediments by rapid shoreline retreat when past global rates of SLR were elevated to the levels projected for the end of the twenty-first century (Fig. 4).

Storm-induced beach ridges in the South Pacific and South Indian Oceans also serve as a reliable marker of tropical cyclone activity, supplementing overwash deposit information from the North Atlantic and North Pacific ${ }^{82}$ (Fig. 4c). These beach ridge tropical-cyclone-proxies are preserved along shorelines that have been prograding, partly due to moderate rates of sea-level fall over the past $6,000-7,000$ years ${ }^{83}$. Similar to back-barrier overwash reconstructions, the onset for the formation of these beach-ridge shorelines begins only after the Holocene transgression. These shorelines were either stationary or retreating landward before this interval, because of rapid rates of relative SLR.

\section{BOX 2 \\ Sea-level rise and Hurricane Sandy}

On October 29, 2012 Hurricane Sandy inundated New York City at high tide, raising water levels to $3.5 \mathrm{~m}$ above mean sea level at the Battery (located at the south end of Manhattan Island). Historical records indicate that this event may have exceeded the maximum water levels of the previous highest recorded flood, during a hurricane in 1821 when the water rose roughly $3.2 \mathrm{~m}$ above mean sea level at the time ${ }^{100}$. However, the 1821 event occurred closer to low tide and when mean sea level at the Battery was roughly $0.5 \mathrm{~m}$ lower than present ${ }^{94}$. If the 1821 event were to occur at today's higher sea level and at high tide the resulting flood level for the event would probably have exceeded that observed during Hurricane Sandy. Thus, although Sandy was potentially record-breaking in terms of the overall water elevation reached, it was certainly not unique in terms of its overall surge, with sea-level rise and tides two of the primary causes of Sandy's very high water levels relative the 1821 hurricane event. Flooding as a result of Hurricane Sandy is shown here along the New Jersey coast.

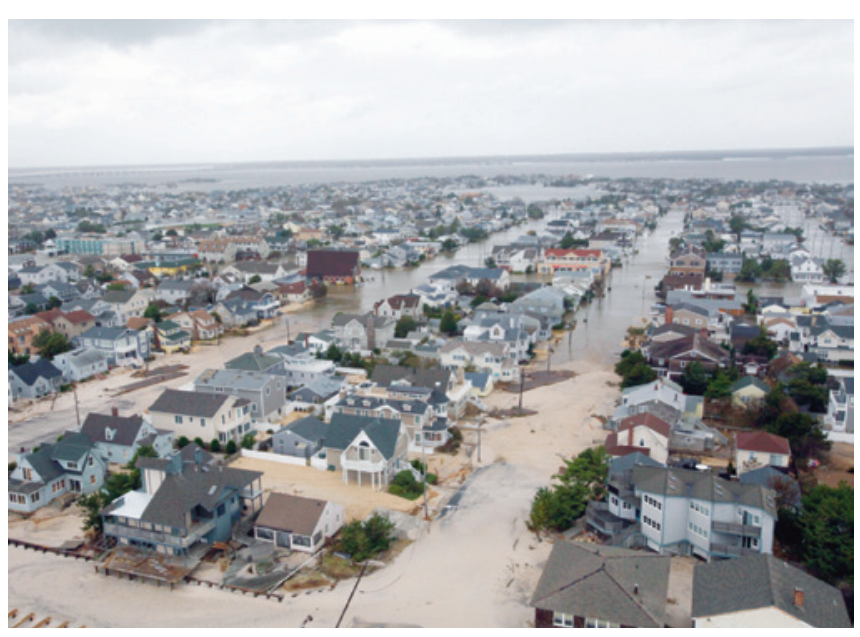



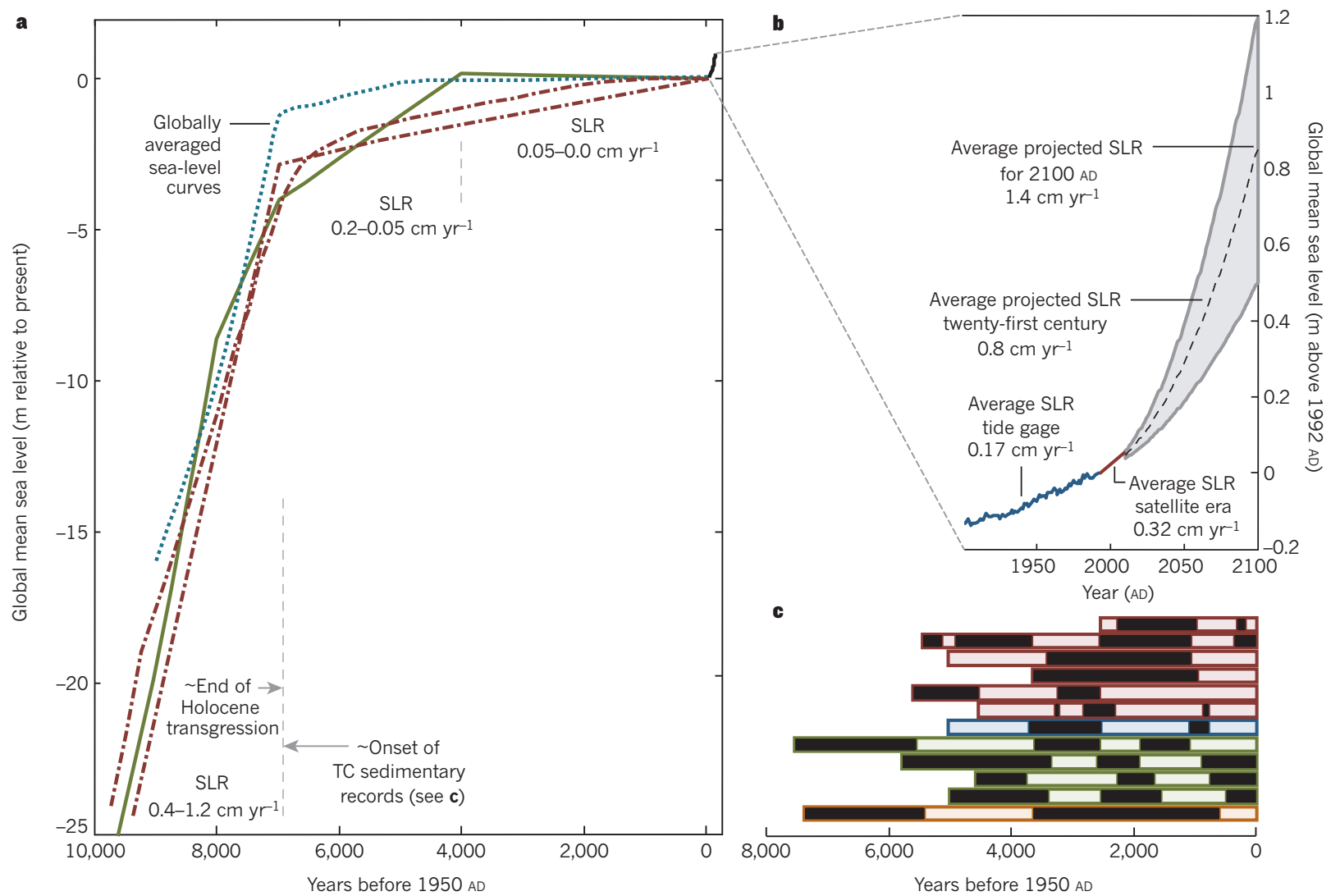

Figure 4 | Mean global sea level along with patterns and extent of preserved sedimentary records of tropical cyclone activity following the most recent glacial maximum. a, Four separate estimates of global sea-level elevation since 10,000 years before present ${ }^{96-98}$, with $\mathbf{b}$, associated SLR observed over the twentieth century $y^{23}$. The twenty-first century projections between intermediate high (IH) and intermediate low (IL) ranges presented in ref. 23 are shaded grey, with the mid-point (dashed line). c, Tropical cyclone activities (adapted from

Tropical-cyclone-derived beach-ridge deposits, therefore, highlight the ability of some coastlines to generally advance seaward over a period of varying tropical cyclone activity, with significant changes in the longterm behaviour of this coastal system driven not by changes in storm activity, but rather by the mid-Holocene transition from rapid rates of SLR during the Holocene transgression to stable or moderate rates of sea-level fall over the past few millennia.

Regional landscapes that were flooded during the Holocene transgression often vary in composition and geometry compared with today's coasts. Thus, the future response of these shorelines to rapid SLR will probably differ somewhat to responses during the early Holocene. However, the marked difference in form and behaviour of most of the world's low-lying sedimentary coastlines during past rapid SLR over the Holocene transgression is a clear example of the importance of sea-level variability in initiating significant changes in shoreline behaviour and, thus, should not be overlooked.

\section{Managing future risk}

By the end of this century there will probably be a higher occurrence of more intense tropical cyclones globally ${ }^{2}$. However, considerable uncertainty is associated with how the smaller subset of landfalling tropical cyclones will change in the future. Efforts are ongoing to provide more robust projections of the occurrence and intensity of these events. Nonetheless, current uncertainties around the effect of future climate change on tropical cyclone activity should not distract from the two additional forces that will drive higher flood probabilities. First, increasing rates of SLR will increase extreme flooding by tropical cyclones. Second, future storm damage will be greatest not where tropical cyclone activity is the

ref. 82). Each rectangular line represents a tropical cyclone reconstruction (see ref. 82 for references for each individual reconstruction) with location grouped by North West Atlantic, red; North West Pacific, blue; South West Pacific, green; and South Indian, orange. Black represents active tropical cyclone periods and light shading less active periods. Sedimentary reconstructions of tropical cyclones exist only for the past few millennia, partly because coastlines were generally more unstable before this period due to increased rates of SLR.

highest, but rather where geomorphic changes along dynamic, populated shorelines greatly enhance storm impacts.

Most coastal populations are not prepared for an increase in extreme flood frequency. Coastal planners and policy makers are challenged by large uncertainties in flood projections related to changing tropical cyclone climatology, SLR and shoreline change. However, despite these uncertainties, the high likelihood of increased catastrophic coastal flooding in the future warrants preparation. Projected increases in coastal development and population will only increase damages from tropical cyclones ${ }^{5}$. Coastal populations need to develop adaptive strategies, which in many cases must include plans and incentives for landward or vertical retreat from the sea. Equally important is the development of proactive policies for planning and engineering in communities that must remain in these vulnerable areas, because of, for example, economic importance, national security or political boundaries. When coastal defences are necessary to protect crucial infrastructure, it is important that they are designed in a way that allows for future modification - because flooding risks will continue to increase over time as SLR accelerates through the twenty-first century (Fig. 4b). Crucial for increasing resilience to the effects of future tropical cyclones are holistic strategies that include consideration of the issues related to changes in sediment supply and subsidence induced by groundwater, oil and gas extraction. Such strategies will be particularly important along and behind barrier beaches as well as for the major deltaic systems on which many coastal megacities exist (Fig. 3).

Coastal communities in developing countries are possibly the most susceptible populations to the adverse effects of increased tropical cyclone flooding ${ }^{35,84,85}$. Here, urban centres and their projected growth 
are generally focused on coastal areas where existing infrastructure and current management strategies are ill equipped for extreme tropical cyclone flooding. In terms of the number of people affected, the impact of future tropical cyclone flooding will probably be focused on key population centres built on broad, low-lying sedimentary coasts ${ }^{86}$ (Fig. 3). Essential strategies for mitigating risk at these locations include improving flood forecasts and developing emergency shelter and effective evacuation procedures ${ }^{85}$.

Humans have adapted to environmental changes in the past. When reacting to a growing hazard, however, it is important to understand its root cause. It is possible that changes in future tropical cyclone activity could be an important component of flood risk, and management strategies will need to be updated as the science advances on this important topic. The evidence is now clear, however, that sea levels are rising and at a rate that will continue to accelerate into the next century. The era of relatively moderate SLR that most coastlines have experienced during the past few millennia is over, and shorelines are now beginning to adjust to a new boundary condition that in most cases serves to accelerate rates of shoreline retreat. The potential for future tropical cyclones to increase in their intensity has served as a prominent example of increased risk that is associated with climate change. This has placed a disproportionate emphasis on still uncertain changes to tropical cyclone characteristics at the expense of factors with a potentially larger and more certain impact, including accelerating SLR, rapidly evolving coastlines and growing coastal populations. The combined consideration of all of these elements is a much more accurate presentation of the compounding factors that society must consider to successfully adapt to future increases in tropical cyclone flooding.

\section{Received 7 April; accepted 23 July 2013.}

1. Peduzzi, P. et al. Global trends in tropical cyclone risk. Nature Clim. Change 2, 289-294 (2012).

2. Knutson, T. R. et al. Tropical cyclones and climate change. Nature Geosci. 3, 157-163 (2010).

This article provides the most current community consensus on projections of future tropical cyclone activity.

3. EM-DAT. The OFDA/CRED International Disaster Database. http://www.emdat.be (CRED, 2013)

4. Pielke, R. A. et al. Normalized hurricane damage in the United States: 19002005. Nat. Hazards Rev. 9, 29-42 (2008)

5. Mendelsohn, R., Emanuel, K., Chonabayashi, S. \& Bakkensen, L. The impact of climate change on global tropical cyclone damage. Nature Clim. Change $\mathbf{2}$, 205-209 (2012).

6. Frank, W. M. \& Young, G. S. The interannual variability of tropical cyclones. Mon. Weath. Rev. 135, 3587-3598 (2007).

7. Weinkle, J., Maue, R. \& Pielke, R. Jr. Historical global tropical cyclone landfalls. J. Clim. 25, 4729-4735 (2012).

8. Gray, W. M. in Meteorology Over the Tropical Oceans (ed. Shaw, D. B. ) 155-218 (Royal Meteorological Society, 1979).

9. Emanuel, K. A. The maximum intensity of hurricanes. J. Atmos. Sci. $\mathbf{4 5 ,}$ 1143-1155 (1988)

This article presents a theoretical foundation for the direct relationship between SST and the intensity of tropical cyclones.

10. Camargo, S. J., Emanuel, K. A. \& Sobel, A. H. Use of a genesis potential index to diagnose ENSO effects on tropical cyclone genesis. J. Clim. 20, 4819-4834 (2007).

11. Tippett, M. K., Camargo, S. J. \& Sobel, A. H. A Poisson regression index for tropical cyclone genesis and the role of large-scale vorticity in genesis. J. Clim. 24, 2335-2357 (2011).

12. Gray, W. M. Atlantic seasonal hurricane frequency. Part I: El Niño and $30 \mathrm{mb}$ Quasi-Biennial Oscillation influences. Mon. Weath. Rev. 112, 1649-1668 (1984).

13. Frank, W. M. \& Ritchie, E. A. Effects of vertical wind shear on the intensity and structure of numerically simulated hurricanes. Mon. Weath. Rev. 129, 2249-2269 (2001)

14. Villarini, G. \& Vecchi, G. A. Twenty-first-century projections of North Atlantic tropical storms from CMIP5 models. Nature Clim. Change 2, 604-607 (2012).

15. Villarini, G. \& Vecchi, G. A. Projected increases in North Atlantic tropical cyclone intensity from CMIP5 models. J. Clim. 26, 3231-3240 (2013).

16. Kim, J.-H., Ho, C.-H., Kim, H.-S., Sui, C.-H. \& Park, S. K. Systematic variation of summertime tropical cyclone activity in the western North Pacific in relation to the Madden-Julian oscillation. J. Clim. 21, 1171-1191 (2008).

17. Barrett, B. S. \& Leslie, L. M. Links between tropical cyclone activity and Madden-Julian Oscillation phase in the North Atlantic and northeast Pacific basins. Mon. Weath. Rev. 137, 727-744 (2009).

18. Stevenson, S. Significant changes to ENSO strength and impacts in the twenty-first century: results from CMIP5. Geophys. Res. Lett. 39, L17703 (2012).

19. Takahashi, C., Sato, N., Seiki, A., Yoneyama, K. \& Shirooka, R. Projected future change of $\mathrm{MJO}$ and its extratropical teleconnection in east Asia during the northern winter simulated in IPCC AR4 models. SOLA 7, 201-204 (2011).

20. Camargo, S. J., Sobel, A. H., Barnston, A. G. \& Klotzbach, P. J. in Global Perspectives on Tropical Cyclones: From Science to Mitigation, Vol. 4 (eds Chan, J. C. L. \& Kepert, J. D.) (World Scientific Publishing Company, 2010).

21. Jones, S. C. et al. The extratropical transition of tropical cyclones: forecast challenges, current understanding, and future directions. Weather Forecast. 18, 1052-1092 (2003).

22. Kossin, J. P. \& Camargo, S. J. Hurricane track variability and secular potential intensity trends. Clim. Change 97, 329-337 (2009).

23. Parris, A. et al. Global Sea Level Rise Scenarios for the US National Climate Assessment. NOAA Tech Memo OAR CPO-1 (NOAA, 2012).

24. Woodworth, P. \& Player, R. The permanent service for mean sea level: an update to the 21st century. J. Coast. Res. 19, 287-295 (2003).

25. Menéndez, M. \& Woodworth, P. L. Changes in extreme high water levels based on a quasi-global tide-gauge data set. J. Geophys. Res. 115, C10011 (2010).

26. Zhang, K., Douglas, B. C. \& Leatherman, S. P. Twentieth-century storm activity along the US east coast. J. Clim. 13, 1748-1761 (2000).

27. Irish, J. L., Resio, D. T. \& Divoky, D. Statistical properties of hurricane surge along a coast. J. Geophys. Res. 116, C10007 (2011).

28. Resio, D. T. \& Westerink, J. J. Modeling the physics of storm surges. Phys. Today 61,33 (2008).

29. Nicholls, R. J. \& Cazenave, A. Sea-level rise and its impact on coastal zones. Science 328, 1517-1520 (2010).

This article outlines future challenges for world regions most vulnerable to future sea-level rise and subsidence.

30. Han, M., Hou, J. \& Wu, L. Potential impacts of sea-level rise on China's coastal environment and cities: a national assessment. J. Coast. Res. 14, 79-95 (1995).

31. Knutson, T. R. \& Tuleya, R. E. Impact of $\mathrm{CO}_{2}$-induced warming on simulated hurricane intensity and precipitation: sensitivity to the choice of climate model and convective parameterization. J. Clim. 17, 3477-3495 (2004).

32. Knutson, T. R. \& Tuleya, R. E. In: Climate Extremes and Society (eds Diaz, H. F. \& Murnane, R. J.) 120-144 (2008).

33. Emanuel, K. Increasing destructiveness of tropical cyclones over the past 30 years. Nature 436, 686-688 (2005)

34. Nicholls, R. J., Hoozemans, F. M. J. \& Marchand, M. Increasing flood risk and wetland losses due to global sea-level rise: regional and global analyses. Glob. Environ. Change 9, S69-S87 (1999).

35. Hanson, S. et al. A global ranking of port cities with high exposure to climate extremes. Clim. Change 104, 89-111 (2011).

36. Ali, A. Climate change impacts and adaptation assessment in Bangladesh. Clim. Res. 12, 109-116 (1999).

37. Church, J. A., Hunter, J. R., McInnes, K. L. \& White, N. J. Sea-level rise around the Australian coastline and the changing frequency of extreme sea-level events. Aust. Meteorol. Mag. 55, 253-260 (2006).

38. Irish, J. L. \& Resio, D. T. A method for estimating future hurricane flood probabilities and associated uncertainty. J. Waterw. Port Coast. Ocean Eng. 139, 126-134 (2013).

39. Lin, N., Emanuel, K., Oppenheimer, M. \& Vanmarcke, E. Physically based assessment of hurricane surge threat under climate change. Nature Clim. Change 2, 462-467 (2012).

This study provides a rigorous evaluation for the combined influence of SLR and future tropical cyclone climate on storm surge probabilities.

40. Smith, J. M., Cialone, M. A., Wamsley, T. V. \& McAlpin, T. O. Potential impact of sea level rise on coastal surges in southeast Louisiana. Ocean Eng. 37, 37-47 (2010).

This is one of a number of important studies that quantify the nonlinear effects on surge by SLR.

41. Rodolfo, K. S. \& Siringan, F. P. Global sea-level rise is recognized, but flooding from anthropogenic land subsidence is ignored around northern Manila Bay, Philippines. Disasters 30, 118-139 (2006).

42. Nicholls, R. J. Coastal megacities and climate change. GeoJournal 37, 369-379 (1995).

43. Wang, J., Gao, W., Xu, S. \& Yu, L. Evaluation of the combined risk of sea level rise, land subsidence, and storm surges on the coastal areas of Shanghai, China. Clim. Change 115, 537-558 (2012).

44. Neumann, J. E., Emanuel, K. A., Ravela, S., Ludwig, L. C. \& Verly, C. WP 2012/81 Risks of Coastal Storm Surge and the Effect of Sea Level Rise in the Red River Delta, Vietnam (UNU-WIDER, 2012).

45. Hoffman, R. N. et al. An estimate of increases in storm surge risk to property from sea level rise in the first half of the twenty-first century. Weather Clim. Soc. 2, 271-293 (2010).

46. Uehara, K., Scourse, J. D., Horsburgh, K. J., Lambeck, K. \& Purcell, A. P. Tidal evolution of the northwest European shelf seas from the Last Glacial Maximum to the present. J. Geophys. Res. 111, C09025 (2006).

47. Hughes, T. P. et al. Climate change, human impacts, and the resilience of coral reefs. Science 301, 929-933 (2003).

48. Hoegh-Guldberg, O. et al. Coral reefs under rapid climate change and ocean acidification. Science 318, 1737-1742 (2007).

49. FitzGerald, D. M., Fenster, M. S., Argow, B. A. \& Buynevich, I. V. Coastal impacts due to sea-level rise. Annu. Rev. Earth Planet. Sci. 36, 601-647 (2008). This paper reviews a century of research on shoreline change in response to changes in sea level. 
50. Goodbred, S. L. Jr, Wright, E. E. \& Hine, A. C. Sea-level change and storm-surge deposition in a late Holocene Florida salt marsh. J. Sediment. Res. 68, 240-252 (1998).

51. Friedrichs, C. T. \& Perry, J. E. Tidal salt marsh morphodynamics: a synthesis. J. Coast. Res. 27, 7-37 (2001)

52. Stumpf, R. P. The process of sedimentation on the surface of a salt marsh. Estuar. Coast. Shelf Sci. 17, 495-508 (1983).

53. Cooper, M. J. P., Beevers, M. D. \& Oppenheimer, M. The potential impacts of sea level rise on the coastal region of New Jersey, USA. Clim. Change 90, 475-492 (2008).

54. Larcombe, P. \& Carter, R. Cyclone pumping, sediment partitioning and the development of the Great Barrier Reef shelf system: a review. Quat. Sci. Rev. 23, 107-135 (2004)

55. Nott, J. Tropical cyclones and the evolution of the sedimentary coast of northern Australia. J. Coast. Res. 22, 49-62 (2006).

56. Cooper, J. A. G. \& Pilkey, O. H. Sea-level rise and shoreline retreat: time to abandon the Bruun Rule. Global Planet. Change 43, 157-171 (2004)

57. Morton, R. A., Paine, J. G. \& Gibeaut, J. C. Stages and durations of post-storm beach recovery, southeastern Texas coast, USA. J. Coast. Res. 10, 884-908 (1994).

58. Ranasinghe, R., Duong, T. M., Uhlenbrook, S., Roelvink, D. \& Stive, M. Climatechange impact assessment for inlet-interrupted coastlines. Nature Clim. Change 3, 83-87 (2012).

59. Morton, R. A. \& Sallenger, A. H. Jr. Morphological impacts of extreme storms on sandy beaches and barriers. J. Coast. Res. 19, 560-573 (2003)

60. Wamsley, T. V., Cialone, M. A., Smith, J. M., Ebersole, B. A. \& Grzegorzewski, A. S. Influence of landscape restoration and degradation on storm surge and waves in southern Louisiana. Nat. Hazards 51, 207-224 (2009).

61. Fagherazzi, S., Carniello, L., D'Alpaos, L. \& Defina, A. Critical bifurcation of shallow microtidal landforms in tidal flats and salt marshes. Proc. Natl Acad. Sci. USA 103, 8337-8341 (2006)

62. Mariotti, G. \& Fagherazzi, S. Critical width of tidal flats triggers marsh collapse in the absence of sea-level rise. Proc. Natl Acad. Sci. USA 110, 5353-5356 (2013).

63. Zhang, K., Douglas, B. \& Leatherman, S. Do storms cause long-term beach erosion along the US East Barrier Coast? J. Geol. 110, 493-502 (2002). This article presents evidence for the dominance of sea-level rise and variations of sediment supply in driving long-term rates of shore-line retreat.

64. Harmelin-Vivien, M. L. The effects of storms and cyclones on coral reefs: a review. J. Coast. Res. 12, 211-231 (1994).

65. Wang, P. et al. Morphological and sedimentological impacts of Hurricane Ivan and immediate poststorm beach recovery along the northwestern Florida barrier-island coasts. J. Coast. Res. 22, 1382-1402 (2006).

66. Done, T. J. Coral community adaptability to environmental change at the scales of regions, reefs and reef zones. Am. Zool. 39, 66-79 (1999).

67. Donoghue, J. F. Sea level history of the northern Gulf of Mexico coast and sea level rise scenarios for the near future. Clim. Change 107, 17-33 (2011).

68. Emery, K., Wigley, R. \& Rubin, M. A submerged peat deposit off the Atlantic coast of the United States. Limnol. Oceanogr. 10, R97-R102 (1965).

69. Field, M. E., Meisburger, E. P., Stanley, E. A. \& Williams, S. J. Upper Quaternary peat deposits on the Atlantic inner shelf of the United States. Geol. Soc. Am. Bull. 90, 618-628 (1979).

70. Pluet, J. \& Pirazzoli, P. World Atlas of Holocene Sea-Level Changes Vol. 58 (Elsevier, 1991)

71. Stanley, D. J. \& Warne, A. G. Worldwide initiation of Holocene marine deltas by deceleration of sea-level rise. Science 265, 228-231 (1994).

72. Kraft, J. C. Sedimentary facies patterns and geologic history of a Holocene marine transgression. Geol. Soc. Am. Bull. 82, 2131-2158 (1971). This article provides evidence for the landward transgression and reworking of the continental shelf by rapid rates of sea-level rise during the early Holocene.

73. Anderson, J., Milliken, K., Wallace, D., Rodriguez, A. \& Simms, A. Coastal impact underestimated from rapid sea-level rise. Eos 91, 205-206 (2010).

74. Rhodes, E. Depositional model for a chenier plain, Gulf of Carpentaria, Australia. Sedimentology 29, 201-221 (1982)

75. Otvos, E. G. Coastal barriers, Gulf of Mexico: Holocene evolution and chronology. J. Coast. Res. 42, 141-163 (2005).

76. Redfield, A. C. Development of a New England salt marsh. Ecol. Monogr. 42, 201-237 (1972).

77. Newman, W. S. \& Rusnak, G. A. Holocene submergence of the eastern shore of Virginia. Science 148, 1464-1466 (1965).

78. Ellison, J. C. \& Stoddart, D. R. Mangrove ecosystem collapse during predicted sea-level rise: Holocene analogues and implications. J. Coast. Res. 7, 151-165 (1991).
79. Parkinson, R. W. DeLaune, R. D \& White, J.R. Holocene sea-level rise and the fate of mangrove forests within the wider Caribbean region. J. Coast. Res. 10, 1077-1086 (1994).

80. Mann, M., Woodruff, J., Donnelly, J. \& Zhang, Z. Atlantic hurricanes and climate over the past 1,500 years. Nature 460, 880-883 (2009).

81. Woodruff, J. D., Donnelly, J. P., Emanuel, K. \& Lane, P. Assessing sedimentary records of paleohurricane activity using modeled hurricane climatology. Geochem. Geophys. Geosyst. 9, Q09V10 (2008).

82. Nott, J. \& Forsyth, A. Punctuated global tropical cyclone activity over the past 5,000 years. Geophys. Res. Lett. 39, L14703 (2012).

83. Lewis, S. E., Sloss, C. R., Murray-Wallace, C. V., Woodroffe, C. D. \& Smithers, S. G Post-glacial sea-level changes around the Australian margin: a review. Quat. Sci. Rev. 74, 115-138 (2013)

84. Dasgupta, S., Laplante, B., Murray, S. \& Wheeler, D. Exposure of developing countries to sea-level rise and storm surges. Clim. Change 106, 567-579 (2011).

85. Webster, P. J. Meteorology: Improve weather forecasts for the developing world Nature 493, 17-19 (2013).

86. Brecht, H., Dasgupta, S., Laplante, B., Murray, S. \& Wheeler, D. Sea-level rise and storm surges: High stakes for a small number of developing countries. J. Environ. Dev. 21, 120-138 (2012)

87. Jarvinen, B. R., Neuman, C. \& Davis, M. NOAA Tech. Memo. NWS NHC-22, A Tropical Cyclone Data Tape for the North Atlantic basin (NOAA, 1988).

88. Chu, J.-H., Sampson, C. R., Levine, A. S. \& Fukada, E. The Joint Typhoon Warning Center Tropical Cyclone Best-Tracks, 1945-2000 (Naval Research Laboratory, 2002).

89. McTaggart-Cowan, R. et al. Analysis of hurricane Catarina (2004). Mon. Weath Rev. 134, 3029-3053 (2006)

90. Permanent Service for Mean Sea Level. Obtaining Tide Gauge Data. http://www. psmsl.org/data/obtaining/ (PSMSL, 2013).

91. United Nations. World Urbanization Prospects, The 2011 Revision. http://esa un.org/unup/ (United Nations, 2012).

92. Karim, M. F. \& Mimura, N. Impacts of climate change and sea-level rise on cyclonic storm surge floods in Bangladesh. Glob. Environ. Change 18, 490-500 (2008)

93. Huang, Z., Zong, Y. \& Zhang, W. Coastal inundation due to sea level rise in the Pearl River Delta, China. Nat. Hazards 33, 247-264 (2004)

94. NOAA. Sea Level Trends. http://tidesandcurrents.noaa.gov/sltrends/ (NOAA 2013).

95. Amante, C. \& Eakins, B. ETOPO1 1 Arc-Minute Global Relief Model: Procedures, Data Sources and Analysis (DOC/NOAA/NESDIS/NGDC, 2008).

96. Fleming, K. et al. Refining the eustatic sea-level curve since the Last Glacial Maximum using far-and intermediate-field sites. Earth Planet. Sci. Lett. 163 327-342 (1998)

97. Milne, G. A., Long, A. J. \& Bassett, S. E. Modelling Holocene relative sea-level observations from the Caribbean and South America. Quat. Sci. Rev. 24 1183-1202 (2005)

98. Peltier, W. R. On eustatic sea level history: last glacial maximum to Holocene. Quat. Sci. Rev. 21, 377-396 (2002).

99. Pugh, D. Changing Sea Levels: Effects of Tides, Weather and Climate (Cambridge Univ. Press, 2004)

100.Scileppi, E. \& Donnelly, J. P. Sedimentary evidence of hurricane strikes in western Long Island, New York. Geochem. Geophys. Geosyst. 8, Q06011 (2007).

Acknowledgements We wish to thank our colleagues for the many comments and suggestions that improved this manuscript, as well as thoughtful discussions at the 2013 Joint AGU/GSA Conference on 'Coastal Processes and Environments Under Sea-Level Rise and Changing Climate: Science to Inform Management'. J.D.W. is funded through the US National Science Foundation (NSF, grant number EAR-1 158780 and EAR-1148244), the Risk Prediction Initiative at the Bermuda Institute of Ocean Sciences (grant number RPI11-1-001/11-5110), and the Hudson River Foundation. S.J.C. acknowledges funding from the National Oceanic and Atmospheric Administration (NOAA, grant number NA110AR4310093 and NA10OAR4310124) and NSF (grant number AGS-1143959 and AGS1064081). J.L.I. received funding for this work through NOAA's National Sea Grant College Program (grant number 24036078) and the South Atlantic Landscape Conservation Cooperative (grant number 24036078). The views expressed herein do not necessarily reflect the views of any of these organizations.

Author Information Reprints and permissions information is available at www.nature.com/reprint. The authors declare no competing financial interests. Readers are welcome to comment on the online version of this article at go.nature.com/f6rg4i. Correspondence should be addressed to J.W. (woodruff@geo.umass.edu). 